\title{
Treatment of paper-recycling wastewater by electrocoagulation using aluminum and iron electrodes
}

\author{
Ali Izadi ${ }^{1} \cdot$ Morteza Hosseini $^{1}$ - Ghasem Najafpour Darzi ${ }^{1} \cdot$ Gholamreza Nabi Bidhendi $^{2} \cdot$ Farshid Pajoum Shariati $^{3}$
}

Received: 22 April 2018 / Accepted: 5 September 2018 / Published online: 15 September 2018

(C) Springer Nature Switzerland AG 2018

\begin{abstract}
Treatment of industrial wastewater by electrocoagulation (EC) is one of the most efficient methods to remove pollutants. Paperrecycling wastewater is a complex mixture containing toxic and recalcitrant substances, indicating complexity and difficulty of its treatment. The aim of the present study was to assess the effectiveness of paper-recycling wastewater treatment by EC process using aluminum ( $\mathrm{Al}$ ) and iron (Fe) plate electrodes. Removal of chemical oxygen demand (COD), total suspended solids (TSS), color and ammonia from paper-recycling mill effluent was evaluated at various electrolysis times (10-60 min), voltage (4-13 V) and $\mathrm{pH}$ (3.5-11). The optimum process conditions for the maximum removal of COD, TSS, color and ammonia from paperrecycling industry wastewater have been found to be $\mathrm{pH}$ value of 7, treatment time of $60 \mathrm{~min}$ and voltage of $10 \mathrm{~V}$. Under optimum operating conditions, the removal capacities of COD, TSS, color and ammonia were 79.5\%, 83.4\%, 98.5\% and 85.3\%, respectively. It can be concluded that EC could be considered as an effective alternative for treatment of paper-recycling wastewater.
\end{abstract}

Keywords Paper-recycling wastewater $\cdot$ Electrocoagulation $\cdot$ Aluminum electrode $\cdot$ Iron electrode $\cdot$ Power consumption

\section{Introduction}

The pulp and paper industry is considered as a highly water-intensive one with significant amounts of wastewater discharge. More than 250 chemicals are produced at different stages of pulp and paper production which are found in the wastewater. Discharge of untreated pollutants into the environment can lead to various environmental problems due to their accumulation in recipient water and soil. This type of wastewater often includes a high level of COD, BOD, wood debris and other contaminants. However, wastewater composition varies according to the type of processes used in the plants [1-4].

Morteza Hosseini

m.hosseini@nit.ac.ir

1 Department of Chemical Engineering, Babol Noshirvani University of Technology, P.O.B. 484, Babol, Iran

2 Faculty of Environment, University of Tehran, Tehran, Iran

3 Department of Chemical Engineering, Science and Research Branch, Islamic Azad University, Tehran, Iran
Several treatment technologies have been applied in order to prevent the harmful effects of effluents on the environment, and therefore, the design and efficiency of wastewater treatment techniques varies among mills [5-7]. The main treatment processes in pulp and paper industries consist of primary clarification (sedimentation or flotation), secondary treatment (activated sludge process or anaerobic digestion) and tertiary processes (membrane processes) [7]. Activated sludge plant has been the most common wastewater treatment process for the removal of organics. However, this process suffers several drawbacks, such as production of sludge with very variable settlement properties, sensitivity to shock loading and toxicity and also the limitation of capacity to remove non-biodegradable substances [8].

However, one of the most interesting and effective processes for treating some pollutants in wastewater is the electrochemical processes. Electrochemical processes can be applied in various configurations such as electrooxidation, electro-precipitation, electrocoagulation, electro-deposition and electro-Fenton $[9,10]$. The electrochemical processes for treatment of water and wastewater are considered advanced oxidation processes which have been widely applied as attractive and suitable 
methods by various benefits including environmental compatibility, adaptability, energy efficiency, selectivity and cost effectiveness [11, 12].

Electrocoagulation as an electrochemical process, which uses an electrical current, has been proved to be an efficient method for the treatment of industrial wastewater [13]. This method allows wastewater to electrochemically oxidize or reduce the organic contaminants to nonhazardous inorganic substances [14] and is specified by simple equipments, environmentally compatibility, safety, selective capacity, easy functionality, short resistance time, negligible equipment for adding chemicals, high efficiency for water purification, stability of sludge and the decreased amount of sludge [15-18].

It is generally accepted that the electrocoagulation process includes three stages: 1) formation of coagulants by electrolytic oxidation of the electrode, 2) the destabilization of contaminants, particulate suspension and breaking of emulsions, 3) aggregation of the destabilized particles to form flocs [19]. In this process, coagulants are produced by the electro dissolution of a sacrificial anode, which is usually made of $\mathrm{Al}$ or $\mathrm{Fe}$. Generation of metal ions occurs at the anode, and hydrogen gas is released from the cathode. The hydrogen gas also helps to float the flocculated particles on the surface of water [20-22].

Anode and cathode reactions for $\mathrm{Al}$ electrodes are as follows (Eqs. 1, 2):

$$
\begin{aligned}
& \text { Anode }: A l \rightarrow A l^{3+}+3 e^{-}\left(E^{0}=1.66 \mathrm{~V}\right) \\
& \text { Cathode : } 3 \mathrm{H}_{2} \mathrm{O}+3 e^{-} \rightarrow 3 / 2 \mathrm{H}_{2}(\mathrm{~g}) \\
& +3 \mathrm{OH}^{-}\left(E^{0}=-0.828 \mathrm{~V}\right)
\end{aligned}
$$

Anode and cathode reactions for Fe electrodes are as follows (Eq. 3-5):

$$
\begin{aligned}
& \text { Anode }: \mathrm{Fe} \rightarrow \mathrm{Fe}^{2+}+2 e^{-}\left(E^{0}=0.44 \mathrm{~V}\right) \\
& \mathrm{Fe}^{2+} \rightarrow \mathrm{Fe}^{3+}+e^{-}\left(E^{0}=-0.771 \mathrm{~V}\right) \\
& \text { Cathode }: 2 \mathrm{H}_{2} \mathrm{O}+2 e^{-} \rightarrow \mathrm{H}_{2}(\mathrm{~g}) \\
& \quad+2 \mathrm{OH}^{-}\left(E^{0}=-0.828 \mathrm{~V}\right)
\end{aligned}
$$

$\mathrm{Fe}^{3+}$ and $\mathrm{Al}^{3+}$ ions generated by electrochemical oxidation in EC process may form monomeric and polymeric irons and aluminum species, which finally transform into $\mathrm{Fe}(\mathrm{OH})_{3}(\mathrm{~s})$ and $\mathrm{Al}(\mathrm{OH})_{3}(\mathrm{~s})$ depending on the $\mathrm{pH}$ of the aqueous medium (Eqs. 6, 7) [21-23].

$$
\begin{aligned}
& \mathrm{Al}^{3+}+3 \mathrm{H}_{2} \mathrm{O} \rightarrow \mathrm{Al}(\mathrm{OH})_{3}(\mathrm{~s})+3 \mathrm{H}^{+} \\
& \mathrm{Fe}^{3+}+3 \mathrm{H}_{2} \mathrm{O} \rightarrow \mathrm{Fe}(\mathrm{OH})_{3}(\mathrm{~s})+3 \mathrm{H}^{+}
\end{aligned}
$$

In other words, the produced $\mathrm{Al}^{3+}, \mathrm{Fe}^{3+}$ and $\mathrm{Fe}^{2+}$ ions react with hydroxyl to form amorphous hydroxide flocs. Accordingly, the mechanism of removing pollutants with both electrodes is associated with formation of $\mathrm{Fe}(\mathrm{OH})_{3}(\mathrm{~s})$, $\mathrm{Al}(\mathrm{OH})_{3}(\mathrm{~s})$, monomeric/polymeric iron and aluminum species [21]. Furthermore, freshly formed amorphous $\mathrm{Al}(\mathrm{OH})_{3}(\mathrm{~s})$ and $\mathrm{Fe}(\mathrm{OH})_{3}(\mathrm{~s})$ sweep flocs in the EC process have large surface areas which are helpful for a rapid adsorption of soluble organic compounds and trapping of colloids [22].

EC process was assessed successfully for treating municipal wastewater [24], landfill leachate [25], textile wastewater $[26,27]$, heavy metal contaminated water and wastewater [28-30], vegetable oil refinery wastewater [31], dairy wastewater [32], dye contaminated wastewater [33] and olive oil mill wastewater [34]. In addition, some studies have reported treatment of pulp and paper mill wastewater using electrocoagulation process [35-38]. However, there has been no reports on treatment of paperrecycling plant wastewater by electrocoagulation using combination of $\mathrm{Al}$ and $\mathrm{Fe}$ electrodes.

Operating cost analysis was conducted for removal of pollutants from wastewater of lather finishing industrial process using EC. The results showed the EC was cheaper compared with the conventional methods. The operational cost of EC was found to be US $\$ 1.7$ per cubic meter of the treated effluent as compared to the cost of US $\$ 3.5$ per cubic meter for conventional methods [39]. It has been reported that the operating cost of chemical coagulation is 3.2 times as high as that of electrocoagulation for the treatment of textile wastewater [40].

In the present study, we have conducted an experimental investigation of treating paper-recycling mill effluent using the electrocoagulation method. The efficiency of electrocoagulation in removing COD, TSS, color and ammonia from paper-recycling mill effluent was explored. The effect of several experimental parameters such as $\mathrm{pH}$, voltage and electrolysis time on the removal efficiency was investigated to determine the optimum operational conditions.

\section{Materials and methods}

\section{Characterization of the paper-recycling mill effluents}

The paper-recycling wastewater samples were taken from Kahrizak paper mill located approximately $10 \mathrm{~km}$ far from Tehran (Tehran province, Iran). All samples were collected manually in 20-1 polyethylene containers and transferred to the laboratory, and they were also stored at $4{ }^{\circ} \mathrm{C}$ to reduce 
biodegradation. The main characteristics of the raw wastewater are presented in Table 1.

\section{Electrocoagulation set-up and measurements}

EC process has been evaluated for the reduction of a wide range of pollutants using batch or continuous mode of operation. Comparably, a batch reactor's dynamic nature allows for studying the range of operating conditions and is better suited for laboratory and pilot plant scale applications, while the continuous system is more suited to industrial processes with large effluent volumes $[11,41]$. As shown in Fig. 1, electrocoagulation experiment was carried out in a batch mode reactor made of Plexiglas with dimensions of $20 \mathrm{~cm} \times 10 \mathrm{~cm} \times$ $17 \mathrm{~cm}$.

In the electrocoagulation process, the electrode type is an important parameter and has a significant effect on removal efficiency. Iron and aluminum plates were used as electrodes in the electrocoagulation process because of their non-toxic nature, being cheap, easy accessibility and simple production $[42,43]$. It has been found when COD, color and phenol removal are important, application of $\mathrm{Al}$ and $\mathrm{Fe}$ electrodes combination has higher efficiency in paper mill wastewater treatment [44]. In our study, there were two iron electrodes between two aluminum electrodes arranged in monopolar configuration and effective area of each electrode was $14 \mathrm{~cm}$ by $8 \mathrm{~cm}$. Samples from the electrocoagulation unit were allowed to settle for $30 \mathrm{~min}$ in a beaker before every analysis. The electrodes were washed with $\mathrm{HCl}$ solution $(15 \% \mathrm{~W} / \mathrm{V})$ before each run. Following each run, the electrodes were washed with distilled water, then dried and used again.

A digital power supply (Zhaoxin RXN-605D), which transform alternating current to direct current, was used as an energy source in EC process at a constant temperature of $23-25^{\circ} \mathrm{C}$ and $100 \mathrm{rpm}$ stirring speed. The maximum output voltage and current of the power supply were $60 \mathrm{~V}$ and $5 \mathrm{~A}$, respectively.

Table 1 Characteristics of paper-recycling mill wastewater

\begin{tabular}{ll}
\hline Characteristics & Paper-recycling mill wastewater \\
\hline Color $\left(\mathrm{Pt}^{\circ} \mathrm{Co}^{\mathrm{a}}\right)$ & 8000 \\
Temperature $\left({ }^{\circ} \mathrm{C}\right)$ & $26-31$ \\
$\mathrm{pH}$ & 7.2 \\
$\mathrm{COD}\left(\mathrm{mg} \mathrm{l}^{-1}\right)$ & 900 \\
$\mathrm{TSS}\left(\mathrm{mg} \mathrm{l}^{-1}\right)$ & 4120 \\
$\mathrm{TDS}\left(\mathrm{mg} \mathrm{l}^{-1}\right)$ & 7000 \\
$\mathrm{NH}_{3}\left(\mathrm{mg} \mathrm{l}^{-1}\right)$ & 4.5 \\
Turbidity $\left(\mathrm{NTU}^{\mathrm{b}}\right)$ & 2440 \\
\hline
\end{tabular}

${ }^{a}$ Platinum cobalt unit

${ }^{\mathrm{b}}$ Nephelometric turbidity unit
Electro-Coagulation Cell

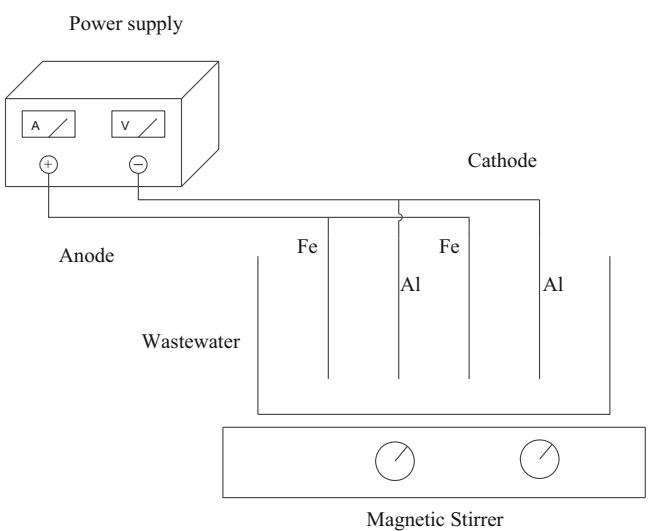

Fig. 1 Bench-scale EC reactor with monopolar electrodes in parallel connection

The measurement of COD, TSS, color and ammonia before and after electrocoagulation was carried out according to the Standard Methods (American Public Health Association standards) [45] to calculate the removal efficiency of pollutants. Concentrations of COD and ammonia were analyzed colorimetrically with a spectrophotometer (Hach DR 5000, USA). The color and turbidity were measured by a Hach DR-2000 spectrophotometer.

\section{Results and discussion}

\section{Effect of electrolysis time}

Electrolysis time influences the treatment efficiency of the EC process. During electrolysis, anodic electro-dissolution leads to the release of coagulant species. Besides, removal efficiency of pollutants depends directly on the concentration of metal ions produced on the electrodes. When the electrolysis time increases, the concentration of metal ions and their hydroxide flocs increases [46, 47]. Theoretically, based on Faraday's law, the amount of released coagulants from aluminum electrodes tends to increase with electrolysis time [48]. Therefore, the graph of pollutants removal versus retention time demonstrate an increasing trend [49].

The COD reduction percentage, as an indicator of the pollutants removal, increased with increasing the electrolysis time. Because the $\mathrm{Fe}(\mathrm{OH})_{3}$ flocs are generated by applying current in the electrodes, and therefore, they adsorb the organic molecules of the effluent [50].

In this study, investigations regarding the effect of electrolysis time on the removal of pollutants were conducted. Figure 2 illustrates the efficiencies of COD, TSS, color and ammonia removal at different electrolysis times $(10,20,30,40,50$, and $60 \mathrm{~min})$ with an initial $\mathrm{pH}$ of 7.2 and a constant cell voltage of $4.0 \mathrm{~V}$. As it is obvious, by increasing electrolysis time, the 
Fig. 2 Effect of treatment time on COD, TSS, color and ammonia removal (initial $\mathrm{pH}$ value of 7.2 and voltage value of $4 \mathrm{~V}$ )

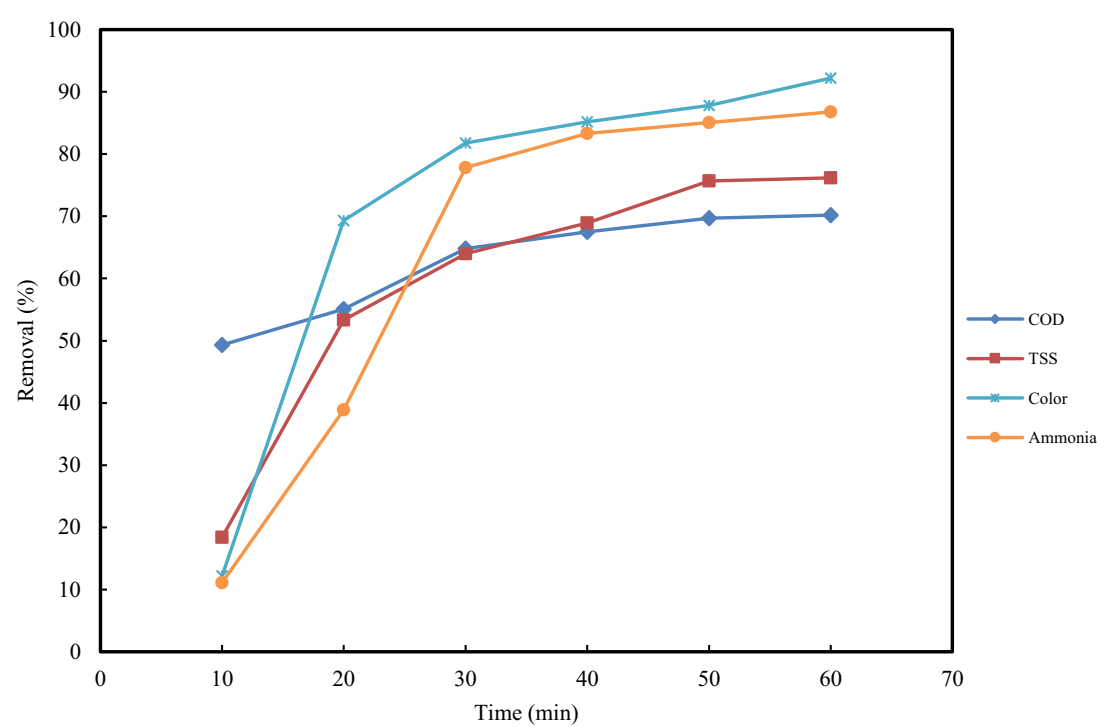

efficiency of pollutants removal increased. In the first half of the operating time, $81 \%$ and $78 \%$ of color and ammonia removal, respectively, were achieved. The generation of $\mathrm{Fe}^{3+}$ at the anode is the reason for particle aggregation-polymerization. Depending on the initial $\mathrm{pH}$ of the wastewater, this ion may form ferric hydroxocomplexes and polymeric species such as $\mathrm{Fe}\left(\mathrm{H}_{2} \mathrm{O}\right){ }_{6}^{3+}$, $\mathrm{Fe}\left(\mathrm{H}_{2} \mathrm{O}\right){ }_{5} \mathrm{OH}^{2+}, \mathrm{Fe}\left(\mathrm{H}_{2} \mathrm{O}\right){ }_{4}(\mathrm{OH})_{2}^{+}, \quad \mathrm{Fe}_{2}\left(\mathrm{H}_{2} \mathrm{O}\right)_{8}$ $(\mathrm{OH})_{2}^{4+}$ and $\mathrm{Fe}_{2}\left(\mathrm{H}_{2} \mathrm{O}\right)_{6}(\mathrm{OH})_{4}^{2+}$. The amount and variety of these species that are key factors in removing contaminants depend on electrolysis time [50, 51].

The removal of TSS, COD and ammonia during the treatment time indicates an approximate steadiness after $50 \mathrm{~min}$, but there is a relatively considerable color removal between 50 and $60 \mathrm{~min}$. Therefore, $60 \mathrm{~min}$ of operation time was applied for further studies.

\section{Effect of voltage}

Current density and voltage are important factors in the electrocoagulation process for removal of contaminants [34, 49]. The voltage of electrolysis is related to the distance of electrodes, conductivity, electrode surface state and current density [52].

As the voltage increases, the length of EC process decreases. Due to a sufficient voltage through the solution, the metal ions generated by dissolution of the sacrificial electrode are hydrolyzed to form a series of metallic hydroxide species. Therefore, these species neutralize the electrostatic charges on the dispersed particles to reduce the electrostatic inter-particle repulsion to the value small enough for the van der Waals attraction to predominate and accordingly facilitate agglomeration [21, 53].
Fig. 3 Effect of voltage on COD, TSS, color and ammonia removal (initial $\mathrm{pH}$ value of 7.2 and operation time value of $60 \mathrm{~min}$ )

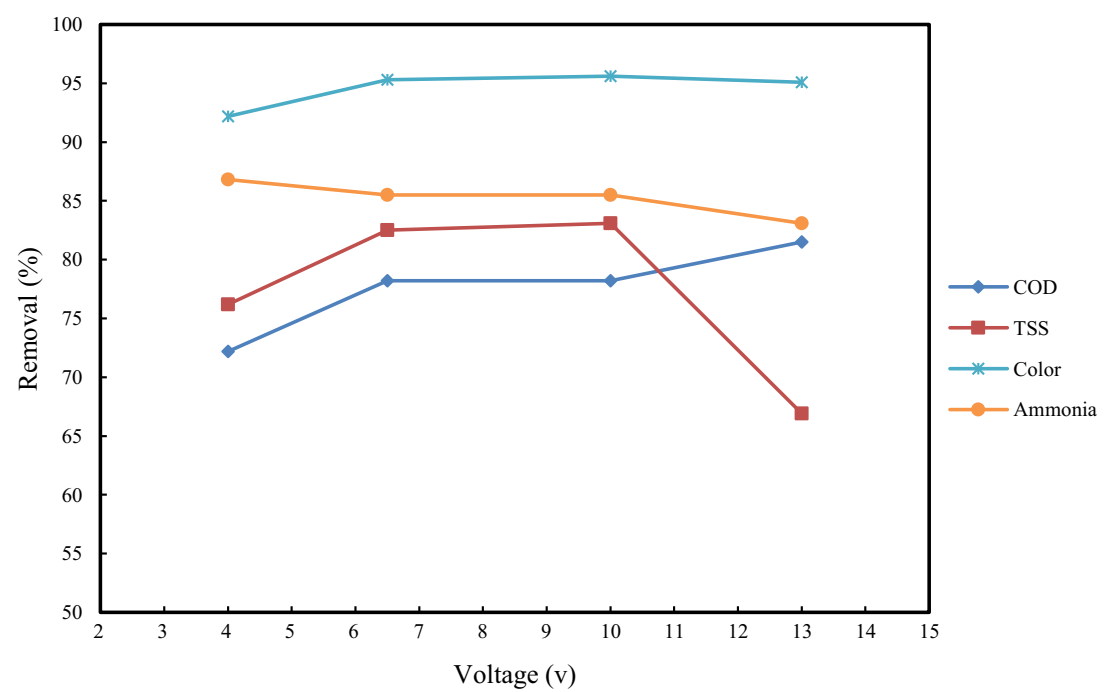


Fig. 4 Effect of $\mathrm{pH}$ on $\mathrm{COD}$, TSS, color and ammonia removal (voltage value of $10 \mathrm{~V}$ and operation time value of $60 \mathrm{~min}$ )

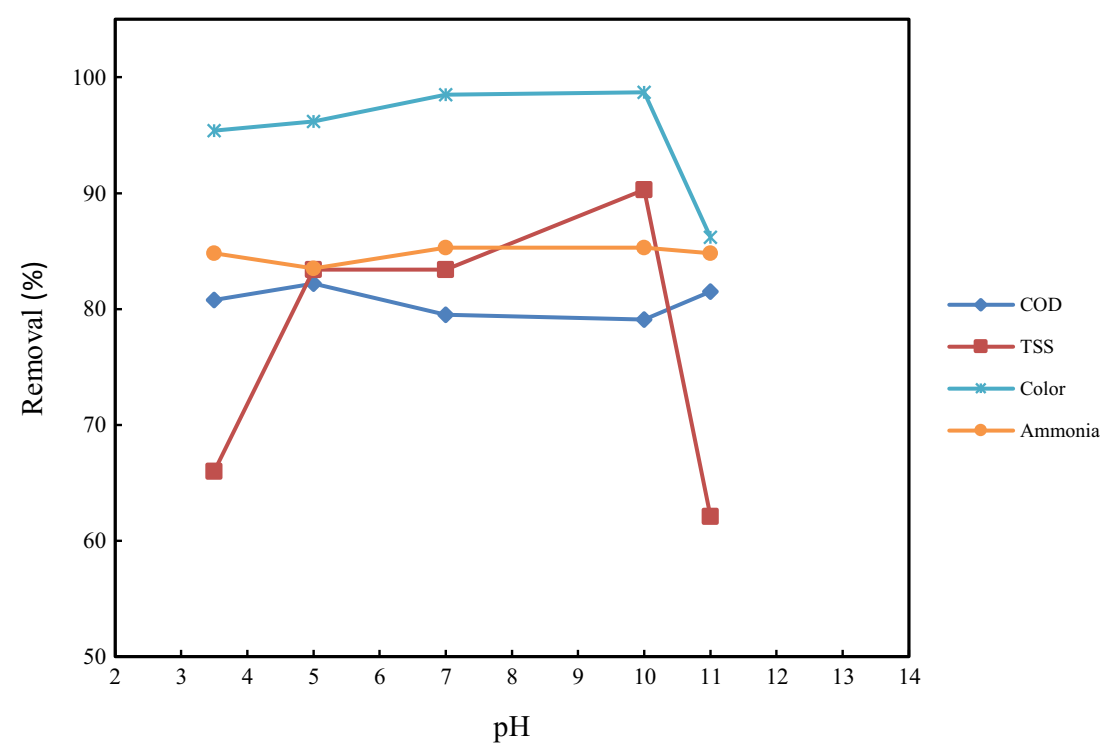

In our experiments, the electrolysis time was set at $60 \mathrm{~min}$ and initial $\mathrm{pH}$ of the wastewater was 7.2. The effect of different voltages $(4,6.5,10,13 \mathrm{~V})$ on the removal of COD, TSS, color and ammonia was investigated. As can be seen in Fig. 3, at $4 \mathrm{~V}$, more than $70 \%$ of pollutants were removed and the efficiency of color removal was greater than $90 \%$. When the applied voltage was raised to $10 \mathrm{~V}$, the removal efficiency of COD, TSS and color rose. Because a larger amount of $\mathrm{Fe}^{2+}$ was produced via anodic metal dissolution, which is able to react with dissolved oxygen of the wastewater according to Eq. (8), causing coagulation and more bubbles formed at the cathode, leading to flotation [50].

$\mathrm{Fe}^{3+}+3 \mathrm{H}_{2} \mathrm{O} \rightarrow \mathrm{Fe}(\mathrm{OH})_{3}(\mathrm{~s})+3 \mathrm{H}^{+}$

Between 10 and $14 \mathrm{~V}$, a decline in TSS removal was observed, and therefore, the optimal voltage for the process was $10 \mathrm{~V}$. Results at this point were $78.2 \%$, $83.1 \%, 95.6 \%$, and $85.5 \%$ for removal of COD, TSS, color and ammonia, respectively.

\section{Effect of initial pH}

The $\mathrm{pH}$ is another important factor that has a notable influence on the performance of electrocoagulation process [44, 54, 55]. As shown in Fig. 4, the removal efficiency of COD, TSS, color and ammonia was analyzed at different $\mathrm{pH}$ values. These experiments were conducted in $60 \mathrm{~min}$ and $10 \mathrm{~V}$, which were the optimum conditions achieved in the previous sections. In order to adjust $\mathrm{pH}$, the $\mathrm{H}_{2} \mathrm{SO}_{4}$ and $\mathrm{NaOH}$ solutions were applied.

The results showed that when $\mathrm{pH}$ of the wastewater was between 5 and 10, removal efficiency of pollutants was optimal, which is close to the optimal $\mathrm{pH}$ range for $\mathrm{Al}(\mathrm{OH})_{3}(\mathrm{~s})$
Fig. 5 The $\mathrm{pH}$ variation of the wastewater before and after treatment (voltage value of $10 \mathrm{v}$ and treatment time of $60 \mathrm{~min}$ )

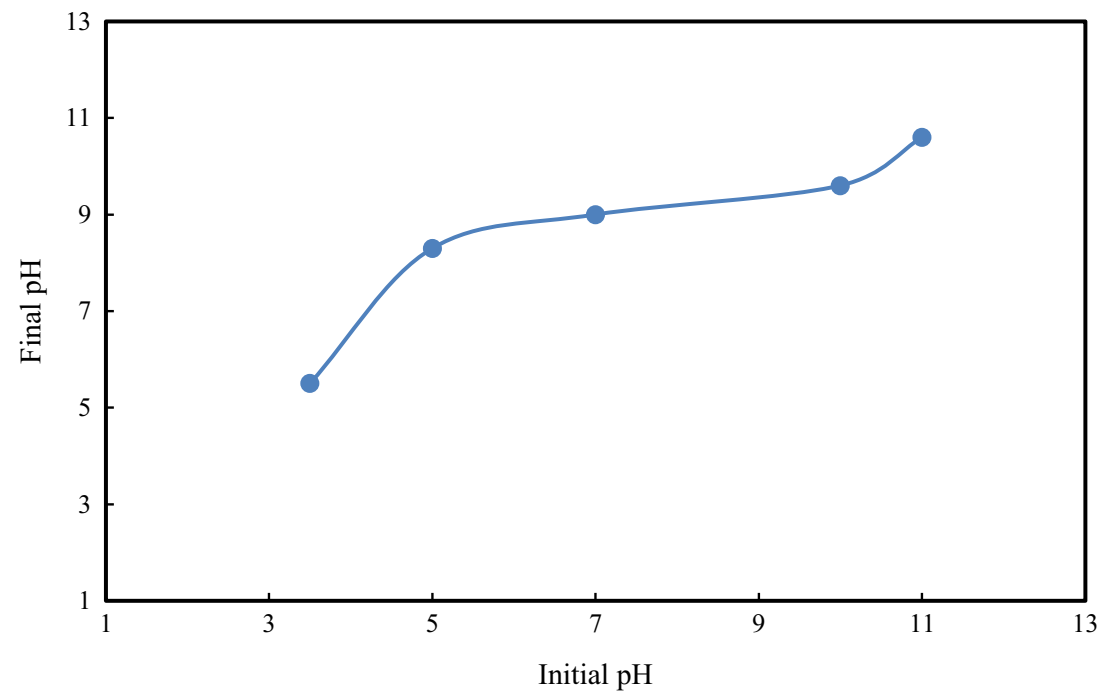


formation. The flocs of $\mathrm{Al}(\mathrm{OH})_{3}(\mathrm{~s})$ have large surface areas, which are useful for a rapid adsorption of soluble organic compounds and also trapping of colloidal particles [46, 56]. $\mathrm{pH}$ of 7 was selected as the optimum value, considering the fact that the initial $\mathrm{pH}$ of raw wastewater was 7.2 (no need to add chemicals), and efficiency of EC at this point is acceptable. At $\mathrm{pH}$ value of greater than 10 , the removal efficiency of color and TSS were reduced because at high $\mathrm{pH}$ solution, the dominant species is $\mathrm{Al}(\mathrm{OH})_{4}^{-}$, which obviously does not coagulate the pollutants [57].

Generally, the $\mathrm{pH}$ of the medium changes during the EC process and this change depends on the type of electrode material and on the initial $\mathrm{pH}[49,58,59]$. According to Fig. 5, at $\mathrm{pH}$ values of less than $7, \mathrm{pH}$ of wastewater increases after treatment by electrocoagulation. This increase was assigned to hydrogen evolution at cathodes [60]. However, this was contested by Chen et al. [61] who described this increase by the release of $\mathrm{CO}_{2}$ from wastewater owing to $\mathrm{H}_{2}$ bubble disturbance. In other words, at low $\mathrm{pH}, \mathrm{CO}_{2}$ is oversaturated in wastewater and can be released during $\mathrm{H}_{2}$ evolution, causing an increasing of $\mathrm{pH}$. In alkaline medium $(\mathrm{pH}>8)$, the final $\mathrm{pH}$ does not change very much, and a slight drop was obtained. This result was in accordance with other reports and suggests that EC can act as $\mathrm{pH}$ buffer because of the balance between the production and the consumption of $\mathrm{OH}$ ion $[34,55,62]$.

\section{Power consumption}

Cost evaluation plays an important role in industrial wastewater treatment because the wastewater treatment technique should be cost-effective. The costs involved in EC mainly include the energy consumption, the electrode consumption and the addition of any external chemical for increasing the efficiency of EC. In general, electrical energy consumption is a very important economical parameter in the electrocoagulation process and can be calculated using the following equation $[11,63,64]$ :

$C_{\text {energy }}=\frac{(U \times I \times t)}{V}$

where $\mathrm{C}_{\text {energy }}$ is the consumed electrical energy $(\mathrm{kWh} /$ $\left.\mathrm{m}^{3}\right), \mathrm{U}$ is the cell voltage $(\mathrm{V}), \mathrm{I}$ is the current in ampere (A), $\mathrm{t}$ is the treatment time (h) and $\mathrm{V}$ is the volume of the solution $\left(\mathrm{m}^{3}\right)$. In this study, the reactor-specific energy consumption under optimum conditions $(\mathrm{pH} 7$, $10 \mathrm{~V}, 60 \mathrm{~min}$ ) was $11.5 \mathrm{kWh} / \mathrm{m}^{3}$.

\section{Conclusion}

Electrocoagulation was assessed as a possible method for the reduction of COD, TSS, color and ammonia concentration in paper-recycling mill wastewater. The influence of variables such as electrolysis time, voltage and initial $\mathrm{pH}$ on the removal of COD, TSS, color and ammonia was determined. Under optimum condition (voltage of $10 \mathrm{~V}$, initial $\mathrm{pH}$ of 7 and operating time of $60 \mathrm{~min}$ ), the removal efficiencies of COD, TSS, color and ammonia were $79.5 \%, 83.4 \%, 98.5$ and $85.3 \%$, respectively. In addition, other parameters including the removal efficiency of TDS and turbidity were measured at the optimum point and their values were $35 \%$ and $99 \%$, respectively. According to the results, this method has demonstrated efficiency in the treatment of paper-recycling wastewater and can be a good alternative for other methods to be used on an industrial scale.

Acknowledgements This study was financially supported by grant No: 950704 of the Biotechnology Development Council of the Islamic Republic of Iran.

\section{Compliance with ethical standards}

Conflict of interest The authors would like to declare that there is no conflict of interest with this research and in the publication.

\section{References}

1. Ali M, Sreekrishnan T. Aquatic toxicity from pulp and paper mill effluents: a review. Adv Environ Res. 2001;5(2):175-96.

2. Kamali M, Khodaparast Z. Review on recent developments on pulp and paper mill wastewater treatment. Ecotoxicol Environ Saf. 2015;114:326-42.

3. Rintala JA, Puhakka JA. Anaerobic treatment in pulp-and papermill waste management: a review. Bioresour Technol. 1994;47(1): $1-18$.

4. Ashrafi O, Yerushalmi L, Haghighat F. Wastewater treatment in the pulp-and-paper industry: a review of treatment processes and the associated greenhouse gas emission. J Environ Manag. 2015;158: 146-57.

5. Birjandi N, Younesi H, Bahramifar N, Ghafari S, Zinatizadeh AA, Sethupathi S. Optimization of coagulation-flocculation treatment on paper-recycling wastewater: application of response surface methodology. J Environ Sci Health A. 2013;48(12):1573-82.

6. Latorre A, Malmqvist A, Lacorte S, Welander T, Barceló D. Evaluation of the treatment efficiencies of paper mill whitewaters in terms of organic composition and toxicity. Environ Pollut. 2007;147(3):648-55.

7. Thompson G, Swain J, Kay M, Forster CF. The treatment of pulp and paper mill effluent: a review. Bioresour Technol. 2001;77(3): 275-86

8. Nagarathnamma R, Bajpai P, Bajpai PK. Studies on decolourization, degradation and detoxification of chlorinated lignin compounds in Kraft bleaching effluents by Ceriporiopsis subvermispora. Process Biochem. 1999;34(9):939-48.

9. Khansorthong S, Hunsom M. Remediation of wastewater from pulp and paper mill industry by the electrochemical technique. Chem Eng J. 2009;151(1-3):228-34.

10. Shen Z, Yang J, Hu X, Lei Y, Ji X, Jia J, et al. Dual electrodes oxidation of dye wastewater with gas diffusion cathode. Environ Sci Technol. 2005;39(6):1819-26. 
11. Bazrafshan E, Mohammadi L, Ansari-Moghaddam A, Mahvi AH. Heavy metals removal from aqueous environments by electrocoagulation process-a systematic review. J Environ Health Sci Eng. 2015;13(1):74.

12. Mansoorian HJ, Mahvi AH, Jafari AJ. Removal of lead and zinc from battery industry wastewater using electrocoagulation process: influence of direct and alternating current by using iron and stainless steel rod electrodes. Sep Purif Technol. 2014;135:165-75.

13. Espinoza-Quiñones FR, Fornari MMT, Módenes AN, Palácio SM, Trigueros DEG, Borba FH, et al. Electrocoagulation efficiency of the tannery effluent treatment using aluminium electrodes. Water Sci Technol. 2009;60(8):2173-85.

14. Sahu O, Mazumdar B, Chaudhari P. Treatment of wastewater by electrocoagulation: a review. Environ Sci Pollut Res. 2014;21(4): 2397-413.

15. Tak B-y, Tak BS, Kim YJ, Park YJ, Yoon YH, Min GH. Optimization of color and COD removal from livestock wastewater by electrocoagulation process: application of box-Behnken design (BBD). J Ind Eng Chem. 2015;28:307-15.

16. Mansouri K, Hannachi A, Abdel-Wahab A, Bensalah N. Electrochemically dissolved aluminum coagulants for the removal of natural organic matter from synthetic and real industrial wastewaters. Ind Eng Chem Res. 2012;51(5):2428-37.

17. Mahvi A, Mansoorian H, Rajabizadeh A. Performance evaluation of electrocoagulation process for removal of sulphate from aqueous environments using plate aluminum electrodes. World Appl Sci J. 2009;7(12):1526-33.

18. Malakootian M, Mansoorian H, Moosazadeh M. Performance evaluation of electrocoagulation process using iron-rod electrodes for removing hardness from drinking water. Desalination. 2010;255(13):67-71.

19. Joseph N, Chigozie U. Effective decolorization of eriochrome black $\mathrm{T}$, furschin basic and malachite green dyes from synthetic wastewater by electrocoag-nanofiltration. Chem Proc Eng Res. 2014;21:98106.

20. Can O, Bayramoglu M, Kobya M. Decolorization of reactive dye solutions by electrocoagulation using aluminum electrodes. Ind Eng Chem Res. 2003;42(14):3391-6.

21. Mollah MYA, Schennach R, Parga JR, Cocke DL. Electrocoagulation (EC)—science and applications. J Hazard Mater. 2001;84(1):29-41.

22. Omwene P, Kobya M. Treatment of domestic wastewater phosphate by electrocoagulation using $\mathrm{Fe}$ and $\mathrm{Al}$ electrodes: a comparative study. Process Saf Environ Prot. 2018;116:34-51.

23. Palahouane B, Drouiche N, Aoudj S, Bensadok K. Cost-effective electrocoagulation process for the remediation of fluoride from pretreated photovoltaic wastewater. J Ind Eng Chem. 2015;22: 127-31.

24. Sharma AK, Chopra A. Influence of operating conditions on the electrolytic treatment for the removal of color, TSS, hardness and alkalinity using Al-Al electrode combination. JANS. 2014;6(1): 279-85.

25. Ilhan F, Kurt U, Apaydin O, Gonullu MT. Treatment of leachate by electrocoagulation using aluminum and iron electrodes. J Hazard Mater. 2008;154(1-3):381-9.

26. Bazrafshan E, Mahvi AH. Textile wastewater treatment by electrocoagulation process using aluminum electrodes. IJHS. 2014;2(1):16-29.

27. Vlyssides A, et al. Electrochemical oxidation of a textile dye wastewater using a Pt/Ti electrode. J Hazard Mater. 1999;70(1-2):41-52.

28. Parga JR, et al. Arsenic removal via electrocoagulation from heavy metal contaminated groundwater in La Comarca Lagunera Mexico. J Hazard Mater. 2005;124(1-3):247-54.

29. Bazrafshan E, et al. Performance evaluation of electrocoagulation process for removal of chromium (VI) from synthetic chromium solutions using iron and aluminum electrodes. Turk J Eng Environ Sci. 2008;32(2):59-66.

30. Nouri J, Mahvi A, Bazrafshan E. Application of electrocoagulation process in removal of zinc and copper from aqueous solutions by aluminum electrodes. Int J Environ Res. 2010;4(2):201-8.

31. Un UT, Koparal AS, Ogutveren UB. Electrocoagulation of vegetable oil refinery wastewater using aluminum electrodes. J Environ Manag. 2009;90(1):428-33.

32. Bazrafshan E, et al. Application of electrocoagulation process for dairy wastewater treatment. J Chem. 2013:2012.

33. Alizadeh M, Mahvi AH, Mansoorian HJ. The survey of electrocoagulation process for removal dye reactive Orange 16 from aqueous solutions using sacrificial iron electrodes. IJHSE. 2014;1(1):1-8.

34. Adhoum N, Monser L. Decolourization and removal of phenolic compounds from olive mill wastewater by electrocoagulation. Chem Eng Process Process Intensif. 2004;43(10):1281-7.

35. Shankar R, Singh L, Mondal P, Chand S. Removal of COD, TOC, and color from pulp and paper industry wastewater through electrocoagulation. Desalin Water Treat. 2014;52(40-42):7711-22.

36. Sridhar R, Sivakumar V, Prince Immanuel V, Prakash Maran J. Treatment of pulp and paper industry bleaching effluent by electrocoagulant process. J Hazard Mater. 2011;186(2-3):1495502.

37. Mahesh S, Prasad B, Mall ID, Mishra IM. Electro chemical degradation of pulp and paper mill wastewater. Part 1. COD and color removal. Ind Eng Chem Res. 2006;45(8):2830-9.

38. Uğurlu M, Gürses A, Doğar Ç, Yalçın M. The removal of lignin and phenol from paper mill effluents by electrocoagulation. J Environ Manag. 2008;87(3):420-8.

39. Espinoza-Quiñones FR, Fornari MMT, Módenes AN, Palácio SM, da Silva FG Jr, Szymanski N, et al. Pollutant removal from tannery effluent by electrocoagulation. Chem Eng J. 2009;151(1-3):59-65.

40. Bayramoglu M, Eyvaz M, Kobya M. Treatment of the textile wastewater by electrocoagulation: economical evaluation. Chem Eng J. 2007;128(2-3):155-61.

41. Khandegar V, Saroha AK. Electrocoagulation for the treatment of textile industry effluent-a review. J Environ Manag. 2013;128:949 63.

42. Inan H, Dimoglo A, Șimșek H, Karpuzcu M. Olive oil mill wastewater treatment by means of electro-coagulation. Sep Purif Technol. 2004;36(1):23-31.

43. Bazrafshan E, et al. Performance evaluation of electrocoagulation process for diazinon removal from aqueous environments by using iron electrodes. IJEHSE. 2007;4(2):127-32.

44. Katal R, Pahlavanzadeh H. Influence of different combinations of aluminum and iron electrode on electrocoagulation efficiency: application to the treatment of paper mill wastewater. Desalination. 2011;265(1-3):199-205.

45. Federation, W.E, A.P.H. Association. Standard methods for the examination of water and wastewater. Washington, DC: American Public Health Association (APHA); 2005.

46. Aoudj S, Khelifa A, Drouiche N, Hecini M, Hamitouche H. Electrocoagulation process applied to wastewater containing dyes from textile industry. Chem Eng Process Process Intensif. 2010;49(11):1176-82.

47. Daneshvar N, Khataee AR, Amani Ghadim AR, Rasoulifard MH. Decolorization of CI acid yellow 23 solution by electrocoagulation process: investigation of operational parameters and evaluation of specific electrical energy consumption (SEEC). J Hazard Mater. 2007;148(3):566-72.

48. Drouiche N, Aoudj S, Hecini M, Ghaffour N, Lounici H, Mameri N. Study on the treatment of photovoltaic wastewater using electrocoagulation: fluoride removal with aluminium electrodescharacteristics of products. J Hazard Mater. 2009;169(1-3):65-9. 
49. Elazzouzi M, Haboubi K, Elyoubi M. Electrocoagulation flocculation as a low-cost process for pollutants removal from urban wastewater. Chem Eng Res Des. 2017;117:614-26.

50. Azadi Aghdam M, Kariminia H-R, Safari S. Removal of lignin, COD, and color from pulp and paper wastewater using electrocoagulation. Desalin Water Treat. 2016;57(21):9698-704.

51. Gürses A, Yalçin M, Doğar C. Electrocoagulation of some reactive dyes: a statistical investigation of some electrochemical variables. Waste Manag. 2002;22(5):491-9.

52. Chen X, Chen G, Yue PL. Investigation on the electrolysis voltage of electrocoagulation. Chem Eng Sci. 2002;57(13):2449-55.

53. Chou W-L, Wang C-T, Chang S-Y. Study of COD and turbidity removal from real oxide-CMP wastewater by iron electrocoagulation and the evaluation of specific energy consumption. J Hazard Mater. 2009;168(2-3):1200-7.

54. Kim T-H, Park C, Shin EB, Kim S. Decolorization of disperse and reactive dyes by continuous electrocoagulation process. Desalination. 2002;150(2):165-75.

55. Chen G. Electrochemical technologies in wastewater treatment. Sep Purif Technol. 2004;38(1):11-41.

56. Bayramoglu M, Kobya M, Can OT, Sozbir M. Operating cost analysis of electrocoagulation of textile dye wastewater. Sep Purif Technol. 2004;37(2):117-25.
57. Holt PK, Barton GW, Wark M, Mitchell CA. A quantitative comparison between chemical dosing and electrocoagulation. Colloids Surf A Physicochem Eng Asp. 2002;211(2-3):233-48.

58. Bleeke F, Quante G, Winckelmann D, Klöck G. Effect of voltage and electrode material on electroflocculation of Scenedesmus acuminatus. BIOB. 2015;2(1):36.

59. Rodrigo M, et al. Electrochemical technologies for the regeneration of urban wastewaters. Electrochim Acta. 2010;55(27):8160-4.

60. Vik EA, Carlson DA, Eikum AS, Gjessing ET. Electrocoagulation of potable water. Water Res. 1984;18(11):1355-60.

61. Chen G, Chen X, Yue PL. Electrocoagulation and electroflotation of restaurant wastewater. J Environ Eng. 2000;126(9):858-63.

62. Kobya M, Can OT, Bayramoglu M. Treatment of textile wastewaters by electrocoagulation using iron and aluminum electrodes. J Hazard Mater. 2003;100(1-3):163-78.

63. El-Ashtoukhy E-S, Amin N, Abdelwahab O. Treatment of paper mill effluents in a batch-stirred electrochemical tank reactor. Chem Eng J. 2009;146(2):205-10.

64. Mohora E, Rončević S, Agbaba J, Tubić A, Mitić M, Klašnja M, et al. Removal of arsenic from groundwater rich in natural organic matter (NOM) by continuous electrocoagulation/flocculation (ECF). Sep Purif Technol. 2014;136:150-6. 